\title{
LA COLECCIÓN DE ETNOGRAFÍA E HISTORIA DE AMÉRICA Y EL EMBAJADOR ROBERTO LEVILLIER EN MÉXICO,
} 1934-1939

\author{
Alexandra Pita González \\ Universidad de Colima
}

INTRODUCCIÓN

Dara los países latinoamericanos fue importante pertenecer a la Sociedad de las Naciones (SDN), primer organismo internacional que, tras el fin de la primera guerra mundial, se propuso establecer el arbitraje como mecanismo obligatorio para la resolución de conflictos. Durante la década de 1920, el vínculo tuvo altibajos por distintos motivos, pero a pesar de las tensiones se mantuvo la mayoría de las adhesiones. ${ }^{1}$ Esta situación cambió a

Fecha de recepción: 25 de abril de 2018

Fecha de aceptación: 26 de julio de 2018

${ }^{1}$ Cabe mencionar que una vez que se firmaba el acuerdo para ingresar a la SDN se daba por sentado que aceptaban el art. 2 del acta constitutiva SDN, el cual afirmaba la compatibilidad con la doctrina Monroe a nivel regional. Sin embargo, cuando la SDN se dio cuenta de que esto generaba dudas a los países latinoamericanos, decidió realizar una discusión interna para explicar sus alcances, pero este artículo no fue retirado con la intención de que Estados Unidos se incorporara (lo cual no sucedió). Al ingresar México a la SDN en 1931, enfatizó que desconocía y desaprobaba tal doctrina, pero esto quedó como una simple “expresión de insatisfacción” porque en la práctica no daba lugar a una reserva. Herrera, México en la Sociedad de Naciones, pp. 63-68 y 119-120. 
finales de esa década e inicios de la siguiente, cuando más países latinoamericanos se incluyeron e involucraron en la resolución de la Guerra del Chaco (conflicto entre Bolivia y Paraguay). Pese a esto, la atención siguió concentrada en asuntos europeos, lo que generó un debate en América Latina sobre la conveniencia de mantener su adhesión. No obstante, el vínculo se mantuvo, entre otras cosas, por la conveniencia de adquirir la experiencia en materia económica y social de Europa, lo cual les permitiría balancear la influencia de Estados Unidos en la región. ${ }^{2}$

Para su funcionamiento, la SDN tenía instancias especializadas. Una de ellas abrió un espacio para los representantes de la cultura y las ideas: el Comité Internacional de Cooperación Intelectual (CICI) en Ginebra, al cual se sumó al poco tiempo el Instituto Internacional de Cooperación Intelectual (IICI) en París y el Instituto Internacional de Cinematografía Educativa (IICE) en Roma. Las instancias de la comisión de Cooperación Intelectual estuvieron conformadas por una élite que, habiéndose destacado en la ciencia, las artes y las letras, participaba en representación de sus países para, como objetivo general, crear conciencia sobre la paz y asociar este concepto a la labor internacional del organismo. Para los intelectuales y diplomáticos latinoamericanos este espacio permitió posicionar a sus países desde un lugar de menor desigualdad que en el resto de los comités. No es extraño entonces que en este espacio se creara, a fines de la década de 1920, la Colección Iberoamericana para traducir al francés obras representativas de la cultura latinoamericana. A pesar de las dificultades financieras tras la crisis de 1929,

\footnotetext{
2 Para estos países era demasiado caro el pago que debían realizar porque veían poco interés de la organización en involucrarse en temas o problemas americanos (como el conflicto Tacna y Arica) o porque veían frustradas sus aspiraciones de alcanzar un asiento permanente en el Consejo. Esto, sin contar con que la inclusión del artículo correspondiente a la doctrina Monroe generó sucesivas quejas. WeHrLI, "New Histories of Latin America at The League of Nations", pp. 2-4.
} 
el emprendimiento logró publicar una docena de libros en la década de $1930 .^{3}$

Esta posibilidad animó al diplomático e historiador argentino Roberto Levillier a proponer al organismo, en 1934, la creación de una colección de etnografía e historia de América dedicada a los siglos XV a XvII, justificando que los avances y descubrimiento en materia documental y arqueológica daban ahora la posibilidad de escribir una historia científica que "objetivamente" demostrara las grandezas de la conquista española.

Aunque ésta no llegó a concretarse, reconstruir los avatares por los que pasó al intentarlo permite entender el complejo entramado de la política internacional, en primera instancia dentro de la Comisión de Cooperación Intelectual, pero, sobre todo, entre México y Argentina (cuando Levillier es nombrado embajador en este país). Partimos de la idea de que, aunque se tratara de una propuesta académica, los comentarios a favor o en contra estuvieron más influenciados por una mirada política preocupada por el complejo panorama internacional de preguerra que por un debate histórico disciplinar, el cual fue casi inexistente. Así, pretender exponer en una serie de tomos la historia de la conquista y la colonización de América fue más allá de defender la leyenda blanca o atacar la negra. Implicó definir la delicada relación de ambos países latinoamericanos con España en un momento de tensión política antes y durante la Guerra Civil.

Pese a que este estudio de caso nos abre una ventana interesante hacia la comprensión de la historia de las relaciones culturales internacionales, en especial de la diplomacia cultural, ${ }^{4}$ ésta

\footnotetext{
3 Pernet, "The spirit of harmony"; Pita, "América [Latina] en París".

${ }^{4}$ La dimensión cultural de las relaciones internacionales estuvo al margen de la historiografía por largo tiempo. Fue necesario el trabajo pionero de Pierre Milza de 1980, tras el cual siguieron los trabajos de Pierre Renouvin, Baptiste Duroselle y los de Robert Frank. Ésta ocuparía la cuarta dimensión de las relaciones internacionales (después de la política, la economía y la defensa). Otros estudiosos propusieron una tipología binaria de estas relaciones: las
} 
ha sido poco estudiada. Los estudiosos de la Comisión de Cooperación Intelectual de la entreguerra la mencionan de manera general como una más de las propuestas que emprendieron los delegados latinoamericanos para representar a sus países en el organismo internacional..$^{5}$ La primera aproximación puntual la realizó Corinne Pernet (2015), quien al estudiar el "espíritu de armonía” que intentó crear la SDN -revisando los libros de texto de historia- explicó la propuesta de Levillier como un proyecto revisionista que no obtuvo el apoyo por distintos motivos: para Gran Bretaña y Estados Unidos se priorizaba excesivamente el colonialismo español; para los funcionarios del IICI era imposible costear la cantidad de volúmenes; para algunos latinoamericanos, como Gabriela Mistral, era un apoyo incondicional a la leyenda blanca de la conquista de América y, por ende, a la España más reaccionaria. ${ }^{6}$

Si bien esto es un punto de partida importante, el presente trabajo ahonda en la colección, no sólo en detalles internos (autores, nacionalidades, títulos) sino al relacionarla con el nombramiento de su mentor como embajador de Argentina en México. Para narrar esta trama, iniciamos explicando cómo el nombramiento de Levillier y la aparición de la propuesta de la colección (entre 1933 y 1935) cayeron bajo sospecha por su hispanismo, mientras el siguiente apartado se centra en los acontecimientos de lo que denominamos el affaire Levillier,

que son espontáneas y las que dependen de políticas culturales. Pero en ambos casos la diplomacia cultural y las relaciones culturales internacionales están ligadas intrínsecamente. Dumont," De la coopération intellectuelle”, pp. 22-25. ${ }^{5}$ La renovación en los estudios sobre cooperación intelectual surge a partir del trabajo de RENOLIET, L'UNESCO onbliée (el cual recupera a su vez el trabajo de KolAsA, International Intellectual Cooperation. Décadas después, y desde una perspectiva distinta, encontramos un debate más amplio sobre la importancia de la cultura en los trabajos de Dumont, L'Institut International de Coopération Intellectuelle et le Brésil; Herrera "México y el Instituto Internacional de Cooperación Intelectual”; PITA, Educar para la paz.

"Pernet, "The spirit of harmony". 
entre 1935 y 1937, esto es, desde que el argentino se ausenta de su brevísima estadía en México como embajador para enfrentar una serie de acusaciones en su país. El último apartado retorna temporalmente a 1935 para retomar las discusiones sobre la factibilidad de la colección y termina en 1939 cuando, pese a seguir nominalmente en marcha, el inicio de la guerra da por terminada la propuesta. Para narrar esta historia que entrelaza tensiones diplomáticas (más que historiográficas), el trabajo utiliza numerosa documentación diplomática (oficiales y confidenciales), proveniente principalmente del archivo del Instituto Internacional de Cooperación Intelectual que guarda la UNESCO en París y del Archivo Diplomático de la Secretaría de Relaciones Exteriores de México.?

\section{EL NOMBRAMIENTO Y LA PROPUESTA}

Antes de dar el acuerdo para que Roberto Levillier fuera nombrado embajador de Argentina en México en junio de 1933 se iniciaron averiguaciones. La primera impresión personal que buscó recabar el entonces secretario de Relaciones Exteriores, Manuel Puig Casauranc, fue la del embajador de México en Argentina, Rafael Cabrera, quien respondió dando un diagnóstico de lo que estaba ocurriendo en aquel país en relación con la designación: existía resistencia entre algunos miembros del gobierno argentino ante tal designación porque Levillier era de origen francés (nacionalizado argentino). Sus orígenes hacían que se dudara que fuera un exponente genuino del país, sin contar con que otros diplomáticos se encontraban resentidos por su rápido ascenso en la carrera.

A esto se sumó la información de sus averiguaciones: nació el 1o de octubre de 1881 en Francia, hijo de Enrique Levillier

\footnotetext{
7 En menor medida se contó con correspondencia de la Biblioteca Nacional Digital de Chile y de la Capilla Alfonsina (México).
} 
y de Ida Andremont, ambos franceses. En 1902 se trasladó a Argentina, donde obtuvo su nacionalidad (5 de noviembre de 1902) en el juzgado federal de la capital bonaerense, ciudad donde realizó sus primeros estudios en el Colegio Nacional y en el Instituto Libre, para después ingresar a la Facultad de Derecho de la Universidad de Buenos Aires, donde cursó hasta el tercer año. Hablaba francés, inglés y español, por lo que se desempeñó como traductor del Ministerio de Obras Públicas durante cuatro años. En 1908 fue secretario del intendente municipal Manuel Güiraldes. Poco después, durante un viaje a España, se le encomendó que realizara investigaciones históricas para la municipalidad, la Facultad de Derecho y el gobierno nacional. En 1918 ingresó a la carrera diplomática como consejero de la embajada en Madrid y encargado de negocios hasta 1922, cuando fue promovido como enviado extraordinario y ministro plenipotenciario. Además, cuenta con varias publicaciones: "Alienados delincuentes”, Orígenes argentinos, La reconstrucción del pasado colonial, cuatro volúmenes de recopilación documental, Gobernadores del Perú, Audiencia de Lima, Chile y Tucumán en el siglo XVI, Repertorio de los documentos históricos, Papeles eclesiásticos del Tucumán, Nueva crónica de la conquista del Tucumán. Por su labor y una conferencia dictada en la Sorbona sobre la conquista y civilización de América, Francia le otorgó la encomienda de la Legión de Honor. Por último, entrando en temas más personales, comentaba que su apellido original era Levi, mismo que cambió para "enmascarar su origen judío". Su esposa era de origen inglés y tenían una hija, pero como no vivían juntos el embajador Cabrera no creía que ésta lo acompañaría a México. Por todo esto, finaliza afirmando que podía dudarse de la información recabada, pero que lo cierto era que se trataba de una persona "inteligente y culta". ${ }^{8}$

8 AHSRE, 24-12-42. Puig a Cabrera, 22 de junio de 1933; Cabrera a Puig, 22 de junio de 1933. 
A esta información le faltaban empero varios detalles sobre sus antecedentes en la prensa y su acercamiento a la historia por medio de la labor en el Archivo de Indias de Sevilla. ${ }^{9}$ Tampoco mencionaba que en sus libros Orígenes argentinos (1912) y La reconstrucción del pasado colonial (1917), pese a su intento de regirse por un criterio científico, su hispanofilia era evidente. ${ }^{10}$ De hecho, en octubre de 1920, la Academia de la Historia

${ }_{9}$ Al trasladarse a Argentina durante su juventud Levillier trabajó en varios periódicos y revistas publicando sobre periodismo deportivo (primero en el diario El País y luego fundó con Carlos Brown El Sport Ilustrado), al tiempo que tradujo del inglés al castellano un trabajo de Elbert Hubbard, Un mensaje a García (desarrollado durante la independencia de Cuba) y trabaja en el Ministerio de Obras Públicas. Mientras realizaba sus estudios de derecho, trabajó en la secretaría privada del intendente de Buenos Aires, Manuel Güiraldes, y publicó monografías de temas variados y algunos cuentos en la revista Nosotros y el diario La Nación. A mediados de 1909, representando a los jóvenes de letras, fue orador (tras Carlos Ibarguren) en el homenaje que le realizaron a Anatole France durante su visita a Buenos Aires. Su acercamiento a la historia inició en 1910, cuando viajó a Europa para estudiar e investigar durante cuatro años en varios archivos, fundamentalmente el de Indias en Sevilla. En París, convivió con otros estudiantes y artistas latinoamericanos de la bohemia (como el mexicano Diego Rivera). Tras el trabajo de archivo publica su primer obra histórica Orígenes argentinos, labor que continúa a su regreso al estudiar la historia argentina del siglo xvi; gracias al apoyo del presidente Roque Sáenz Peña regresa a España para recabar más documentación. Ahí dictó conferencias en el Ateneo de Madrid y, en 1915, publicó cuatro volúmenes. En 1917 reunió una serie de artículos y memorias expuestas en los años anteriores sobre el tema bajo el título La reconstrucción del pasado colonial. KaTZENSTEIN, Roberto Levillier, pp. 8-17. CAILlET-Bois, “Roberto Levillier”, pp. 157-158. 10 Levillier, La reconstrucción del pasado colonial, pp. 5-7, 23-25. Parte de esta preocupación por hacer científica la labor de la historia lo llevó a presentar unos años antes un proyecto de creación de un centro internacional de investigaciones históricas en el Congreso de Historia y Geografía (1914). Su función principal sería registrar las investigaciones realizadas en los archivos americanos o europeos para conocer qué se ha estudiado y por cuáles autores. El material sería reunido en una biblioteca y se publicaría una revista para difundir esta información. Esto gozaría del apoyo de los gobiernos, quienes utilizarían a sus diplomáticos en España con el fin de crear un consejo. Con ello se contrarrestaría la tendencia "separatista" de Hispanoamérica. 
(en España) le había otorgado el premio de la Fiesta de la Raza por su labor en la publicación de documentos del Archivo de Indias. ${ }^{11}$ En su discurso de recepción del premio e ingreso a dicha academia, el argentino se designó "el arquitecto" dedicado a edificar el "monumental palacio" de la obra de España en América. Los hechos destruirían "las injustas acusaciones, permitiendo honrar el pasado". ${ }^{2} \mathrm{El}$ discurso fue interpretado por los hispanistas como un logro importante para impedir la “desespañolización de América" realizada durante el siglo xIx. ${ }^{13}$ Otro elemento que no se mencionó era que sus primeros trabajos fueron cuestionados fuertemente por miembros de la nueva generación de historiadores (como Rómulo Carbia) por ser una transcripción de documentos sin una crítica que aportara al conocimiento histórico. ${ }^{14}$

Dado que Levillier se había desempeñado recientemente en Varsovia como embajador (entre otros cargos dentro de la diplomacia desde 1916), ${ }^{15}$ se solicitó también la opinión del

11 Real Academia de la Historia, "Premio hispano-americano para la Fiesta de la Raza”, octubre de 1920, pp. 456-458.

12 Levillier, 15 de octubre de 1920, documentos oficiales, pp. 459-461.

13 Raza Española. Revista de España y América, 1921, vol. 3, XXVIII, solemnidad histórica hispanoamericana, pp. 56-61.

14 Entre 1914 y 1920 se libraron una serie de debates entre historiadores de Argentina asociados con la Nueva Escuela Histórica para afianzar la cientificidad del campo disciplinar. Hubo una serie de intercambios polémicos entre los jóvenes integrantes y Paul Groussac para eliminar su lugar hegemónico, así como entre ellos para discutir la validez de sus trabajos. PAGANO y RodRíGUEZ, “Las polémicas historiográficas”, pp. 35-36, 41-42.

15 Levillier había ingresado en 1916 a la carrera diplomática al ser designado por el presidente Hipólito Yrigoyen jefe de la secretaría privada de Honorio Pueyrredón, ministro de Relaciones Exteriores y Culto. Como parte del servicio diplomático es enviado a Madrid en 1918 como consejero de la embajada y asume también como encargado de Negocios (ante la enfermedad del titular). Al finalizar la primera guerra mundial se invita a Argentina a adherirse al pacto de la Conferencia de la Paz en París, por lo que Levillier es nombrado secretario general de la delegación trasladándose a Ginebra, y tras el abandono de Argentina de la Asamblea acompaña temporalmente al secretario 
representante de México en aquel país, quien afirmó conocerlo desde hacia siete años, por lo que no dudó en afirmar que era un intelectual brillante, un historiador y literato que dictaba conferencias y participaba en revistas de historia, por lo que conocía la historia de México "profundamente" y que en aquel momento se encontraba recopilando documentos en el Archivo de Indias para una obra de este país. Pese a esto, lo califica como "extraordinariamente reaccionario". Ante esta información, la cancillería telegrafía a Buenos Aires para comunicar que el gobierno daba el acuerdo solicitado para que Levillier pudiera ser nombrado embajador. ${ }^{16}$

El nombramiento se retrasó un año porque el Senado de Argentina aún no lo había aprobado por los argumentos mencionados

a Londres y regresa en 1921 a Madrid. Su labor diplomática se conjuga con su investigación histórica, de la cual surgen numerosas publicaciones sobre personajes y procesos durante el siglo xvI. En 1922, tras un breve paso por Argentina, se traslada a Perú como ministro plenipotenciario, donde conoce a Jeannette Beatson, de origen escocés, quien estudió los tejidos preincaicos de Paracas y con quien se casaría en 1925. La estancia fue fructífera para seguir investigando en archivos, e intensa como diplomático ante el conflicto entre Perú y Chile (por los territorios de Tacna y Arica). En 1927 se traslada a Portugal como ministro por poco tiempo pues al año siguiente debe trasladarse a Varsovia para atender tres legaciones: las de Polonia, Checoslovaquia y Finlandia (entre 1928 y 1934). En 1932 pide licencia y viaja a Francia para dictar una serie de conferencias para homenajear la obra de la conquista española, pero al año siguiente asume una misión especial del gobierno argentino para que dé a conocer entre los países europeos (y de preferencia sume adhesiones) el Pacto Antibélico de No Agresión y Conciliación. En 1934 se incorpora a la delegación argentina para asistir a la XV Asamblea de la sDn. KaTZENSTEIn, Roberto Levillier, pp. 8-17. CAILlET-Bois, “Roberto Levillier”, pp. 157-158. Durante su estancia en Perú como embajador (1922-1924) dedicó incansables esfuerzos para que, durante el festejo del centenario de la batalla de Ayacucho, Argentina mantuviera influencia en la región. Para ello, realizó una serie de maniobras con los movimientos a fin de revalorar la figura de San Martín (a la que otros diplomáticos intentaron subordinar a la de Bolívar). Ortemberg, “Geopolítica de los monumentos", pp. 22-25.

16 AHSRE, 24-12-42, Puig a Legación de México en Varsovia, 22 de junio de 1933; Joublanc a Puig, 24 de junio de 1933; 26 de junio de 1933, telegrama. 
anteriormente (origen judío y francés). Para Cabrera esto no era razón para afectar su nombramiento porque a su juicio, Levillier se había ganado un prestigio por su labor en el Instituto Internacional de Cooperación Intelectual y su labor destacada como historiador americano, por lo que su estancia en México era, para él, de sumo interés. Aclaraba que, pese a que el nombramiento podría realizarse próximamente, el argentino debería permanecer en Europa hasta fin de ese año para concluir una misión de su gobierno (conseguir apoyo de países europeos al pacto antibélico). ${ }^{17}$

Durante su estancia en Europa, Levillier participó en la asamblea de la SDN y aprovechó su estancia en Ginebra para proponer al cici la creación de una colección etnográfica e histórica de América (septiembre de 1934). La propuesta fue aprobada, pero se pidió al director del IICI que, después de pedir consejo al comité de publicaciones de la Colección Iberoamericana en la próxima sesión, sometiera al comité ejecutivo de la CICI la idea de que se constituyera un comité ejecutivo de americanistas para que realicen el plan científico y financiero de trabajo con el fin de presentarlo en la siguiente asamblea de la SDN, la cual decidiría en definitiva sobre la propuesta. ${ }^{18}$

Las repercusiones fueron inmediatas. Los primeros en reaccionar fueron los españoles: Antonio Ballesteros Beretta, integrante del Seminario de Estudios Americanistas de la Facultad

17 AHSRE, 24-12-42, Cabrera a Puig, 24 de julio de 1934. El Pacto Antibélico o Pacto de No Agresión y Conciliación fue gestionado por Saavedra Lamas, canciller del gobierno de Agustín Justo. Fue lanzado tras la revolución popular que derrocó a la dictadura de Gerardo Machado en Cuba en 1933, como un "mecanismo de paz alternativo al esfuerzo norteamericano de panamericanizar los conflictos”, que buscaba retomar el liderazgo regional a través de la resolución de las disputas por medios pacíficos de conciliación y arbitraje. Fue firmado por Argentina, Brasil, México, Paraguay y Chile en Río de Janeiro (10 de octubre de 1933). Escudé y Cisneros, Historia de las Relaciones Exteriores, http://www.argentina-rree.com/9/9-005.htm, consultado el 3 de abril de 2018. 18 AU, IICI, DD.X.6, Proposición de Levillier. Septiembre de 1934. 
de Filosofía y Letras de la Universidad de Madrid, le escribió a Bonnet para trasmitirle la disposición de dicho seminario para contribuir en la Colección Iberoamericana. ${ }^{19}$ Agregó que tenían un amplio conocimiento de los manuscritos realizados por los indígenas americanos que se encontraban en archivos y bibliotecas españolas. ${ }^{20}$ Era evidente que el eco en España era favorable porque, como se titulaba un artículo de la prensa, la propuesta de Levillier era una "revisión de la Leyenda Negra" al reivindicar la leyenda blanca. ${ }^{21}$

Para convencer al IICI de la importancia de la nueva colección, Levillier remitió una lista confidencial con los títulos de los trabajos y los autores que el argentino pensaba serían deseables para ésta. Proponía 35 volúmenes concentrados temporalmente en los siglos XVI y XvII, que respetaban espacialmente al continente americano, aunque sólo se planteaban estudios específicos para Argentina, México, Brasil, Venezuela, Colombia y Estados Unidos. Los otros trabajos abarcaban problemáticas relacionadas con los conquistadores y navegantes europeos, las rutas marítimas, los estados políticos europeos del momento y la concepción del padre Vitoria y de Las Casas. Nada se menciona sobre el impacto de la conquista en los indígenas, dedicando sólo

19 Es posible que esta confusión de colecciones se deba a que aún no se había decidido, dentro de la SDN si la nueva colección propuesta por Levillier quedaría a cargo del comité de publicaciones de la iberoamericana o si se crearía una nueva, como propuso el argentino en su carta.

20 AU, IICI, DD.X.6, Antonio Ballesteros Beretta a Henri Bonnet, 3 de octubre de 1934.

${ }^{21}$ AU, IICI, DD.X.6, recorte periodístico del 16 de enero de 1935. La leyenda blanca es aquella que defendía a ultranza la España católica, realizando una apología de la madre patria, mientras que la negra cuestionaba la crueldad y opresión ejercida durante la conquista y colonización. Para 1943 el argentino Rómulo Carbia publica un libro sobre la historia de esta leyenda, el cual, aunque expresamente hispanista y católico, intenta reconstruir la trayectoria de esta crítica desde el padre Las Casas, quien fue el primero en señalar la "impropiedad del modo en que se realiza la prédica”. Zavala, reseña de la Historia de la Leyenda Negra, pp. 149-150. 
un libro a las leyes y ordenanzas destinadas a ellos y su aplicación en el siglo Xvi. Sobre el primer periodo colonial se planeaba un libro acerca de la organización de órdenes religiosas, el Estado y la iglesia, el derecho internacional (antes y después de la conquista), la influencia del descubrimiento en la economía europea, las crónicas de Indias, la imprenta y la educación. Para ello escogió a autores americanos y europeos (predominando españoles, argentinos, estadounidenses y peruanos), en su mayoría profesores de universidades que en pocas ocasiones se encontraban cumpliendo funciones diplomáticas (véase el anexo 1). Para demostrar la capacidad de cada uno, adjunta una breve sinopsis mencionando cargos, la institución donde trabajan y sus libros más importantes. ${ }^{22}$

Para seguir sumando apoyo, se creó un Comité de Patronato de la Colección Americana Etnológica e Histórica, en la que participaban numerosas personalidades del ámbito de la historia, la arqueología y la etnología de América y Europa. Levillier insistía en la colección como un estudio internacional metódico que reconstruiría la historia compartida por todos estos países, es decir, la historia de América. Aclaraba que la colección, dedicada a las "culturas primitivas", pondría de relieve el "grado sorprendente de civilización alcanzado por los indígenas antes de la llegada de los conquistadores", visión que se justificaba a partir de los hallazgos arqueológicos y documentales de los últimos 30 años. Esta mención no demeritaba la "destacada labor conquistadora” realizada por España y Portugal, que aportaron en esta "épica fascinante y excepcional". Agregaba que la colección buscaba alejarse de las "concepciones injustas basadas en resentimiento", para que se pudiera otorgar a una opinión pública letrada (bibliotecarios, profesores y estudiantes universitarios) fuentes de primera mano. Constituiría "un

${ }^{22}$ AU, IICI, DD.X. 6, Comité de Patronato de la Colección Americana Etnológica e Histórica. Lista, 10 de diciembre de 1934. 
instrumento de trabajo para los sabios y una fuente precisa de información general”. En suma, pretendía reunir por medio del conocimiento a los “antiguos” países que colonizaron América con los nuevos países que les deben su existencia. ${ }^{23}$

Es interesante señalar que esta última palabra, existencia, fue tachada y arriba puesto a mano "su origen”. Desconocemos si el cambio fue de Levillier o del director del IICI, pero evidencia la conciencia de que la perspectiva del proyecto generaría reacciones y que éstas debían ser matizadas para lograr cierto consenso. Cambiar existencia por origen es significativo. No restaba al juicio en torno al papel predominante de los países ibéricos en la conquista y colonización durante los siglos XVI y XVII, pero sí agregaba la posibilidad de pensar que siglos después estos países

${ }^{23}$ AU, IICI, DD.X.6, Plan provisional de la colección americana etnográfica e histórica, s.f. Por Argentina: Roberto Levillier (embajador de Argentina en México) y Ricardo Levene (historiador, presidente de la Universidad de La Plata). Brasil: Alfonso Celso (Instituto Histórico y Geográfico). Checoslovaquia: M. Osusky (ministro de Checoslovaquia en París). Chile: Ricardo Donoso (Sociedad Chilena de Historia y Geografía). Dinamarca: profesor P. Norlund (Museo Nacional de Copenhague). Ecuador: Gonzalo Zaldumbide (ministro plenipotenciario de la legación de Ecuador en Berna) y Jacinto Jijón y Caamaño (etnólogo americanista). España: Salvador de Madariaga (miembro del Comité Permanente de Letras y Artes), Ramón Menéndez Pidal (profesor de la facultad de Filosofía de Madrid, presidente de la Academia de la Lengua Española, director del Centro de Estudios Históricos), José María Ots (profesor de la Facultad de Sevilla, director del Instituto Hispano Cubano). Estados Unidos: A.L. Kroeber (profesor de Antropología en la Universidad de Berkeley) y H. E. Bolton (profesor de la Universidad de Berkeley). Francia: Paul Rivet (profesor y director del Museo de Etnografía). Gran Bretaña: T. A. Joyce (conservador de la sección americana del Museo Británico). Italia: Almagia (profesor de la Universidad de Roma) y Valerio Callegari (profesor de la Universidad del Sagrado Corazón de Milán). México: Reygadas Vértiz (director de Servicios Arqueológicos) y Alfonso Caso (profesor de la Universidad Nacional). Noruega: H. Shetelig (profesor de la Universidad de Bergen). Perú: Francisco García Calderón (ministro de Perú). Polonia: Stolyhwo (presidente del Instituto de Ciencias Antropológicas). Portugal: M. da Veiga Simoès (ministro de Portugal en Berlín) y M. de Castro (delegado de Portugal ante el IICI). Venezuela: M. Parra Pérez (ministro de Venezuela en Roma). 
pudieron independizarse. Así, aunque Levillier no mencionó jamás en su introducción la expresión leyenda blanca o negra para referirse al debate que se provocó dentro de la disciplina histórica al interpretar (y tomar partido de) la conquista, es evidente -por la temporalidad que eligió para estudiar, los autores y temas que sugirió, así como por su propia justificación- que tomó partido por una leyenda blanca de la historia de América matizada por el cientificismo de los hallazgos arqueológicos y documentales.

El director de la Colección Iberoamericana, Dominique Braga, consideró necesario solicitar la opinión de los miembros del Comité de Publicaciones. Al escribir a Gabriela Mistral, definió el proyecto de Levillier como una "serie de obras originales sobre las culturas indígenas americanas y sobre los viajes de los españoles y portugueses en el siglo Xv". ${ }^{24}$

Mistral respondió que dicha propuesta era "tanto admirable como espinosa" porque se corría el riesgo de interpretar la historia de América desde una perspectiva hispanista cometiendo “imprudencias y fealdades". Para limitar esto, ella incorporó a las sesiones del comité a Díez-Canedo, un español que se ganó el odio de sus colegas españoles porque enseñó en Estados Unidos una historia en que se exponía la verdad sobre las civilizaciones precolombinas en América (la maya y la quechua). Por todo esto era indispensable que se buscaran especialistas franceses, alemanes y estadounidenses "con un criterio de veracidad y no de negación y prejuicio malo respecto a estos pueblos". Caso contrario, los españoles impondrían sus materiales, "páginas sectarias de sus historiadores de Indias", que negaban por completo las investigaciones que se habían realizado en los últimos años. ${ }^{25}$

${ }^{24}$ AU, IICI, F.VI.6, Dominique Braga a Gabriela Mistral, 26 de octubre de 1934.

${ }^{25}$ AU, IICI, F.VI.6, Gabriela Mistral a Dominique Braga, 26 de noviembre de 1934. 
Pocos meses después, Braga envió a Mistral, junto con otros temas de la Colección Iberoamericana, diversos documentos sobre el proyecto de Levillier. ${ }^{26} \mathrm{~A}$ la chilena le pareció muy ofensivo que apareciera una sección en la que se reivindicara la labor de conquista española y portuguesa. Estaba convencida de que la propuesta había sido aceptada por la Asamblea de la SDN sólo porque no se había dado detalle: caso contrario, sería impensable que delegados de México, Chile y otros países latinoamericanos aceptaran lo correspondiente al padre Las Casas, "el apóstol de las Indias", el cual representa una figura moral de la conquista y "es objeto de veneración total que ninguna crítica extranjera podrá disminuir ni ensombrecer”. Basándose en la lectura del proyecto y en las conferencias que Levillier dictó en Madrid, afirmó categóricamente que era un ataque "de singular gravedad" a la labor misionera del religioso. De apoyarlo, el IICI entraría en el terreno polémico de la leyenda negra y blanca, lo que contradiría el espíritu de neutralidad de la SDN y lastimaría el prestigio de la Colección Iberoamericana. Para finalizar le presenta dos soluciones: se rechaza todo el proyecto o éste debería ser financiado por España, puesto que América Latina no pagaría por "desmantelar" a uno de sus héroes. ${ }^{27}$ Bonnet intentó ahuyentar sus dudas, insistiendo en que se trataría de una historia neutral, pero fue imposible porque Levillier se negó a escuchar comentarios que no fueran de especialistas (categoría

${ }^{26}$ BNDCH, Dominique Braga a Gabriela Mistral, 27 de marzo de 1935.

27 AU, IICI, DD.X. 6, Gabriela Mistral a Henri Bonnet, 24 de mayo de 1935. Efectivamente, la opinión de Levillier sobre Las Casas era categórica. Como expuso en un curso dictado en París en 1932, publicado en la Revue d'Histoire Moderne de París, los indios no tenían cualidades pacíficas ni eran libres cuando llegaron los españoles, por lo que la obra La destrucción de las Indias fue escrita "con el exclusivo fin de presionar el espíritu del rey y de los teólogos reunidos en Valladolid y provocar una reacción radical en las leyes destinadas a regular las relaciones entre los españoles y los indios”. Por ello, Levillier considera a Las Casas un buen sacerdote pero un mal historiador. CoRnejo, Levillier, p. 59. 
en la cual sólo se incluían él y el francés Paul Rivet). A partir de esto, Bonnet se distanció del proyecto, sugiriendo que se conformara una comisión editorial y que cuando encontraran los fondos, el Instituto se involucraría nuevamente. ${ }^{28}$

\section{EL AFFAIRE LEVILLIER}

Las conferencias que Levillier dictó en Madrid a inicios de 1935 fueron alarmantes para el encargado de negocios de la embajada mexicana, quien escribió a las autoridades en México para alertarlos acerca de la propuesta del argentino. Para el mexicano, la manera en que se trataba la conquista de América no era científica, porque halagó "hasta el paroxismo el sentimiento patriótico de la mayoría de los españoles”. Su estupor fue tal que decidió hablar con el conferencista para dejarle en claro la "verdad histórica” de los mexicanos: no culpan a España, sino a su tiempo, de "los desmanes de la conquista" (actos de crueldad, de tortura), los cuales eran inolvidables. Rescató a fray Bartolomé de Las Casas y al padre Vitoria, quienes denunciaron los abusos y "pecados” de los conquistadores en contra de los aborígenes. Poco después lo invitó a la embajada de México en aquel país para conversar con otros diplomáticos, pero la reacción de Levillier le demostró que los rumores que había escuchado eran ciertos: no era un historiador "científico", sino un oportunista que cambiaba las versiones según fuera el espectador. Para dar una muestra fidedigna a la cancillería envió varios recortes de prensa madrileña en los cuales se afirmaba que España no había despojado de las tierras a los aborígenes puesto que estas "razas" eran conquistadores de otras tierras. Por si esto fuera poco, acusó al padre Las Casas de ser el creador de la leyenda negra sin conocer más que una parte de América, sin documentos, sólo por "su fantasía entregada al delirio

28 Pernet, “The spirit of harmony”, pp. 144-145. 
caritativo". El encono del mexicano por esta ofensa a quien tanto se venera en México hizo que intentara desenmascararlo al agregar dos últimos datos curiosos que seguían sumando sospechas del argentino. ${ }^{29}$

Pese a estos comentarios, Levillier continuó su viaje a México para asumir como embajador, llegando a fines de marzo a la capital, donde buscó sumar apoyos para su colección. ${ }^{30}$

Logró que la Junta Directiva de la Sociedad Argentina en la capital mexicana invitara a una reunión el martes 14 de mayo en su salón de sesiones (ubicado en la calle Justo Sierra 19 de la ciudad de México), para tratar de "la obra de Levillier". ${ }^{31}$ $\mathrm{Al}$ parecer, en la reunión estuvieron presentes diplomáticos de otros países porque poco después el delegado de la legación de El Salvador en México escribió al argentino para decirle que la información había sido transmitida a las autoridades y que la universidad de su país se adhería a la propuesta. ${ }^{32}$

A esta respuesta siguieron otras. R. Aguiller, miembro de la Sociedad Mexicana de Geografía y Estadística, le escribe a Levillier para informarle que dicha sociedad se adhiere al plan provisional de la colección, y que además designarán a un delegado para que participe en la elección de los representantes de México ante el Comité del Instituto de Cooperación Internacional, y también se nombró a una comisión dentro de la misma Sociedad para que se encargara de la coordinación con otras

\footnotetext{
29 AHSRE, 24-12-42, encargado de negocios al srio. Relaciones Exteriores, 4 de febrero de 1935. El Debate "La leyenda negra será definitivamente borrada", 17 de enero de 1935 y $A B C$ "Segunda Conferencia del Sr. Levillier", 19 de enero de 1935.

30 AHSRE, 24-12-42, Castillo Nájera al srio. Relaciones Exteriores, 14 de marzo de 1935.

31 AU, IICI, DD.X.6, invitación. Mayo 1935. El presidente y vicepresidente de dicha Sociedad eran Pastor Rouaix y Manuel Balerzo, respectivamente. 32 AU, IICI, DD.X.6, Antonio Álvarez a Roberto Levillier, 12 de junio de 1935.
} 
instituciones científicas y culturales en México para participar en dicha propuesta. ${ }^{33}$

El mismo día, Levillier recibió una carta de la Academia Nacional de Historia y Geografía de México para adherirse al plan provisional de la colección, aclarando que ya habían distribuido los ejemplares que les habían enviado. ${ }^{34}$ Más adhesiones llegaron de México: la rectoría de la Universidad Nacional Autónoma, la que le informó que recibieron los ejemplares que envió sobre el plan de la colección y que fueron entregados a Alfonso Caso, director del Instituto de Historia, y a Enrique O. Aragón, decano de la Facultad de Filosofía y Letras, ambos de dicha universidad. Confirmaba que esta universidad se adhería a la propuesta de la colección. ${ }^{35}$ De manera más cautelosa, el Instituto Panamericano de Geografía e Historia (IPGH), con sede en la ciudad de México, también informó que la propuesta se presentaría en el Séptimo Congreso Científico Americano dentro de la Sección de Indigenistas y en el Segundo Congreso del Instituto Panamericano de Geografía e Historia para que todos los países pudieran enterarse de dicha idea. ${ }^{36}$

Puesto que no se trataba de una propuesta vanguardista, sino tradicional dentro del campo historiográfico, el apoyo más decidido lo recibió de abogados y no de historiadores. Para Ezequiel Obregón, quien prologó el trabajo de Levillier Comentarios sobre la aplicación de las leyes de Indias (conferencia publicada por la Academia Mexicana de Jurisprudencia y Legislación en 1935), el embajador argentino llegó a México para “animarnos en la lucha por la cultura de nuestros antepasados europeos". ${ }^{37}$

33 AU, IICI, DD.X.6, R. Aguiller a Roberto Levillier, 29 de junio de 1935.

34 AU, IICI, DD.X.6, Enrique E. Shuiz a Roberto Levillier, 29 de junio de 1935.

35 AU, IICI, DD.X.6, Fernando Ocaranza a Roberto Levillier, 1ำ de julio de 1935.

36 AU, IICI, DD.X.6, Pedro C. Sánchez a Roberto Levillier, 3 de julio de 1935.

37 Connejo, Levillier, pp. 63-64. 
Pero esto no era suficiente. Levillier le escribió a Alfonso Reyes, quien se encontraba como embajador en Brasil, para solicitarle que consiguiera más adhesiones entre los intelectuales y profesores de las universidades de Río de Janeiro y São Paulo dedicados a la historia y la geografía, el derecho y la arqueología. Su intención era que se adhirieran más países antes de septiembre, cuando se reuniría la Asamblea de la sDN en Ginebra con el fin de lograr la sanción definitiva del proyecto. Por ello, adjunta ejemplares del proyecto, el cual -advierte- ya había sido entregado a los diplomáticos, academias, sociedades científicas, institutos y universidades. ${ }^{38}$

Cinco meses después, el argentino le escribe de nueva cuenta para avisarle que el común amigo, Rodrigo Octavio, consiguió la adhesión de la Academia Brasileña de Letras y de la Academia de Legislación Internacional. Espera que, gracias a la gestión de Rodrigo y su apoyo, consigan aún las adhesiones de la Universidad de Río de Janeiro y el Instituto Histórico y Geográfico Brasileño. Era indispensable que todos los países de América estuvieran de acuerdo en la Colección y la apoyaran financieramente, dado que parecía imposible pedirle a la SDN en esos momentos que costeara la suma total (entre 30 y 40000 francos franceses para publicar cinco volúmenes por año en inglés, francés y español, lo cual cubriría tanto la impresión como un apoyo para que un grupo de personas se dedicara sólo a esto en el IICI). ${ }^{39}$

Esta última carta la escribió desde Buenos Aires, ciudad donde Levillier se encontraba desde agosto de 1935, después de diez años de ausencia de su país. Los motivos del viaje (por el cual solicitó licencia) generaron dudas a la cancillería mexicana, por lo que se mantuvo atenta a lo que diría a la prensa bonaerense. En Buenos Aires se había realizado un cambio en la embajada

38 CA-INBA, Ricardo Levillier a Alfonso Reyes, 26 de junio de 1935.

39 CA-INBA, Ricardo Levillier a Alfonso Reyes, 15 de noviembre de 1935. 
de México, quedando a cargo el exsecretario Puig, quien tenía antecedentes de Levillier y se dedicó a realizar una indagación sobre los motivos reales del viaje. ${ }^{40}$

Al hacer escala en Santos (Brasil), dio una entrevista al Diario da Noite de São Paulo en la cual afirmó que México, como país, pero sobre todo la ciudad capital, era una prueba de la falsedad de la calumnia inventada contra los españoles de que robaron todas las riquezas coloniales. Adentrándose en terrenos más escabrosos del presente, reconoció las bondades de la Revolución en el aspecto social, al legislar para que los indios tuvieran los mismos derechos que los blancos. Al arribar a Buenos Aires dio una serie de entrevistas a la prensa local. El encabezado del diario Crítica decía: "Manuel Ugarte y A. [Alfredo] Palacios son queridos en Méjico tanto como el propio Cárdenas". Afirmaba que Argentina era querida especialmente en aquel país y que esto se debía a Manuel Ugarte y Alfredo Palacios, legislador socialista, autor de El porvenir de América Latina, a quienes el pueblo quería mucho. Nada menciona sobre el presidente Cárdenas, detalle que debió haber alarmado a la cancillería tanto como la mención de los dos conocidos antiimperialistas cercanos al socialismo. Como era de esperar, El Diario Español (de Buenos Aires) declaró a Levillier "Un gran hispanófilo que aprendió en sus investigaciones históricas a admirar la grandiosa obra española en América”. En cambio, el diario Crisol mostró su enojo ante el alboroto que causaba la visita del argentino y lo acusó de no ser representativo de su país, de ser un arribista de la diplomacia tras haber pasado de ser un "oscuro joven empleado en el Ministerio" durante la primera presidencia de

\footnotetext{
${ }^{40}$ Al llegar a Buenos Aires el embajador Puig escribió solicitando información sobre cuál es o cree que es el "significado especial" de ese viaje. A esto se respondió de inmediato: su gobierno lo llamó para utilizarlo probablemente como delegado en Ginebra para la próxima asamblea de septiembre. AHSRE, 24-12-42, Puig a srio. de Relaciones Exteriores y srio. de Relaciones Exteriores a Puig, 1 de agosto de 1935.
} 
Hipólito Yrigoyen, a un funcionario de la diplomacia gracias a "una indiscutida discreción para agradar a los gobernantes". Por último, lo acusaban de ser un "propagandista gratuito" de Ugarte y Palacios, pero esa afirmación debía ser castigada por la cancillería porque generaría la creencia de que "los socialistas están aquí muy próximos a llegar al poder". ${ }^{41}$ La crítica de este diario aumentó en un artículo que lo declaraba "desertor", al enterarse del proceso judicial que se estaba realizando porque Levillier no se había enrolado a tiempo como era obligatorio según la ley. Pese a que el embajador mexicano en Buenos Aires no tenía mayor información sobre el proceso, sospechaba que Manuel Ugarte (a quien halagó en el artículo) pudiera conseguir el apoyo de los senadores socialistas para que apoyaran la Ley de Amnistía que lo salvaría del juicio. ${ }^{42}$

Además, se quejó porque no se mencionaron de las acciones de la cancillería mexicana en ciertos temas de política exterior, sin contar el "tono místico" de sus palabras, que comprende por ser una "actitud de judío converso, que extrema su catolicismo para ser mejor aceptado en la nueva y consoladora fe". ${ }^{43}$ Pocos días después informó a México que la prensa capitalina guardaba silencio sobre el asunto, pero en cambio la de provincia declaró abiertamente que el nombre real era Roberto Levi, que era francés y que había ascendido demasiado rápido en la cancillería. Esta maniobra de silenciar la prensa capitalina era para él una muestra de que el gobierno intentaba salvar a Levillier, pero si no

${ }^{41}$ AHSRE, 24-12-42, Puig al srio. Relaciones Exteriores, 2 de septiembre de 1935; Ceniceros a Puig, 9 de septiembre de 1935. Crítica, 14 de agosto de 1935; El Diario Español, 18 de agosto de 1935; Crisol, 18 de agosto de 1935.

42 AHSRE, 24-12-42, Puig al srio. de Relaciones Exteriores, 11 de septiembre de 1935. Crisol, "Levillier, embajador y desertor", 8 de septiembre de 1935.

43 AHSRE, 24-12-42, Puig al srio. de Relaciones Exteriores, 14 de septiembre de 1935. El Hogar, "Don Roberto Levillier, diplomático y escritor, refiere cómo se nos mira en el extranjero" (misma fecha). 
lo lograba perdería la ciudadanía por naturalización y, por ende, finalizarían ipso facto sus actividades diplomáticas. ${ }^{44}$

Mientras se esperaba la resolución del problema, Levillier se reunió con los presidentes de las asociaciones españoles en aquella ciudad, quienes le expresaron su gratitud "por las campañas hispanistas” que realizó en Perú y en España. Para la conmemoración del descubrimiento de América dictó una conferencia que era una apología de la obra de España en América. Lo que más irritaba a Puig era no sólo su parcialidad hacia lo español para justificar sus errores, sino que, citando al padre Sepúlveda, mostrara desprecio al indio. Además, en su afanoso homenaje a España termina criticando la colonización inglesa. ${ }^{45}$

El proceso parecía pronto a solucionarse: el ministro de Guerra accedió a que se retirara del expediente el documento militar donde se daba fe de que no realizó el trámite, por considerar que no pudo cumplir con éste al encontrarse entonces en Europa, faltando entonces que el fiscal y las cámaras aceptaran. Mientras tanto, Levillier esperaba que le otorgaran el Premio Nacional de Literatura. Cargando de nuevo contra él, Puig envió un recorte del diario Crisol, el cual en un tono abiertamente antisemita rechazaba la posibilidad de que pudieran darle un premio a ese "judío audaz" que no era argentino. ${ }^{46}$ Pese a esto, Levillier fue galardonado en primer lugar junto con Ramón J. Cárcano. Al otorgársele el premio, volvió a ser presentado como un historiador y diplomático prestigioso, autor de un reciente

${ }^{44}$ AHSRE, 24-12-42, Puig al srio. de Relaciones Exteriores, 23 de septiembre de 1935. El Argentino (La Plata), 20 de septiembre de 1935, "Uno de los más prestigiosos diplomático argentinos se halla en una curiosa situación".

45 AHSRE, 24-12-42, Puig al srio. de Relaciones Exteriores, 11 de octubre de 1935 y 17 de octubre de 1935. El Diario Español (Buenos Aires), "La Asociación Patriótica Española”, 14 de octubre de 1935.

46 AHSRE, 24-12-42, Puig al srio. de Relaciones Exteriores, 23 de octubre de 1935. Crisol, "El judío y diplomático 'argentino' ”, Roberto Levillier, 22 de octubre de 1935. 
libro, Don Francisco de Toledo ${ }^{47}$ Puig se dio a la tarea de leerlo de inmediato, encontrando de nuevo "el criterio hispanófilo", por lo que duda que, como expresó con motivo de su premio, la colección de arqueología e historia no fuera una apología de la colonización española. La verdadera intención de Levillier no era regresar a México, sino que lo nombraran embajador de su país en España. ${ }^{48}$

Al tiempo que se sucedían las intrigas, se recibían documentos firmados por ambos presidentes (México y Argentina) donde se acreditaba a Levillier como embajador. ${ }^{49}$ Las críticas comenzaron de nuevo. Según los rumores, el breve silencio tras su premio se debía a que la Iglesia católica decidió "reconciliarse" con el diplomático. Rompiendo el silencio, Crisol, pese a ser un órgano clerical, volvió al ataque al publicar en un mismo día dos artículos para desprestigiarlo y acusar a México de ser una mala influencia ("roja") para Argentina. En el primero se quejaban de que sus advertencias no fueron escuchadas por el jurado que otorgó el premio, como tampoco por los jueces que decidieron no quitarle la nacionalidad. La segunda nota, en cambio, tras denunciar el poder que tenían "elementos izquierdistas" en el magisterio (como el socialista Repetto), cuestionaba su propuesta para intercambiar maestros con México: “¿qué tienen que hacer los maestros argentinos en México?, ¿iignora el Consejo que en México es oficial la enseñanza socialista-comunista?, ¿lo ignora el señor Levillier, que no ha puesto su ciudadanía

47 La Nación, "Don Francisco de Toledo", 27 de octubre de 1935 y "Otorgáronse los premios nacionales de letras correspondientes al año de 1931”, 31 de octubre de 1935. La Prensa, "Roberto Levillier acaba de publicar una nueva obra histórica", 27 de octubre de 1935.

48 AHSRE, 24-12-42, Puig al srio. de Relaciones Exteriores, 2 de noviembre de 1935. Puig al srio. de Relaciones Exteriores, 12 de noviembre de 1935. La Prensa, "Demostración en honor al Doctor Roberto Levillier", y La Nación, "Fue agasajado Don Roberto Levillier", 10 de noviembre de 1935.

49 AHSRE, 24-12-42, Puig al srio. de Relaciones Exteriores, 4 de noviembre de 1935. 
argentina de naturalización en regla?, y, ¿no es acaso, ésta una prueba más del lento trabajo de zapa que los rojos hacen dentro de la escuela argentina?". ${ }^{50}$

La ausencia de México se prolongó más de lo pensado debido a que el ministro argentino Saavedra Lamas decidió que lo requería en Europa para seguir obteniendo adhesiones al pacto antibélico. Para Puig, empero, esto se vinculaba con que el juicio aún se encontraba pendiente, pues el Congreso se reuniría en mayo de 1936. Por todo esto no veía con desagrado un cambio definitivo en la embajada en México, puesto que, amén de toda la polémica e intriga comentada, la única proposición que había realizado sobre las relaciones entre ambos países era a su juicio "impráctica” ${ }^{51}$ Poco después Levillier fue acreditado como delegado de Argentina ante la Conferencia de Paz del Chaco. Nuevamente sus afirmaciones generaron polémica y rechazo, ${ }^{52}$ por lo que la Secretaría en México entendió que no regresaría al país. ${ }^{53}$

50 AHSRE, 24-12-42, Puig al srio. de Relaciones Exteriores, 14 de noviembre de 1935.

51 AHSRE, 24-12-42, Puig al srio. de Relaciones Exteriores, 12 de diciembre de 1935. La propuesta de Levillier a la que hace referencia Puig es sobre una embarcación que viene de Venezuela y que podría ir de Buenos Aires a Veracruz (directo) con mercaderías argentinas solicitadas previamente en México y que de regreso trajera a puerto argentino productos mexicanos. Al no ver esto como una propuesta práctica, porque sería "difícil de llenarse" y ventajoso para los argentinos, decidió no telegrafiarles, sino escribirles, sólo a título informativo.

52 Tras la finalización del conflicto del Chaco, Levillier declaró a la prensa que Saavedra Lamas había sido el actor principal sobre el cual recayó el arreglo de la guerra entre Paraguay y Bolivia por el Chaco. La afirmación generó indignación de otros ministros sudamericanos que llamaron molestos para reclamar su participación. Levillier tuvo que disculparse y "rectificar" sus comentarios. Palacios y Covarrubias, Historia de las relaciones, México y los conflictos, p. 280.

53 AHSRE, 24-12-42, Puig a srio. de Relaciones Exteriores, 9 de enero de 1936, y de Luis Garrido al embajador de México en Argentina, 21 de enero de 1936. 
Tras un año de ausencia, el nuevo embajador de México en Argentina, Alfonso Reyes, conversó con él para recabar información sobre sus planes. Al parecer, no volvería a México porque lo nombrarían embajador en Uruguay, aunque "el movimiento tardará en hacerse público".${ }^{54}$ En abril de 1937 regresó sigilosamente a México para recoger sus cosas, pero no se despidió protocolarmente del presidente Cárdenas, sino que lo hizo por medio de un telegrama. En respuesta, el mandatario le telegrafió un mensaje al encargado de negocios mexicano en Buenos Aires para que se lo transmitiera al presidente argentino (debido a que ignoraba dónde se encontraba Levillier). En el mensaje se le sigue considerando como embajador en México y se espera que, tras el restablecimiento de la salud de su esposa, regrese al país "donde se le aprecia debidamente". ${ }^{5}$

Hacia finales de agosto, Levillier sustituyó al embajador Paulino Llambí Campbell en Montevideo (quien a su vez lo reemplazó en México). Al llegar a la capital uruguaya, fue entrevistado por varios medios periodísticos, a los que habló "con entusiasmo de México", con "términos muy elogiosos", en especial de la labor realizada por el presidente Cárdenas no sólo en relación con los avances modernos (vialidad, medios de transporte), sino porque supo menguar la lucha religiosa (cristera) al "buscar la templanza y tolerancia en este sentido, realizando así un bien general para la libertad de cultos". Explicó que en aquel país el comunismo no había ganado la batalla, y aunque "predominan ciertas ideas de izquierda, jamás se apartan de la democracia republicana". La exageración es tal, afirmaba, que en aquel país la figura de Trotsky "no influye para nada en la política mexicana y no deja de ser

54 Sobre la función de Reyes en esta relación bilateral remitimos a ZuLETA, “Alfonso Reyes y las relaciones México-Argentina”.

55 AHSRE. 24-12-42, telegrama 14 de abril de 1937 y del director del ceremonial al encargado de negocios mexicanos en Argentina, 17 de abril de 1937. 
ideológicamente un simple exiliado que para nada pesa en el movimiento del pueblo". ${ }^{56}$

Las intrigas terminaron cuando la deuda con México quedó saldada, por lo que al recibir oficialmente el anuncio del presidente argentino, general Agustín P. Justo, el presidente Cárdenas respondió expresando que al haber terminado la misión del embajador Levillier, reconocía que éste "contribuyó a estrechar las relaciones de fraternal amistad que felizmente unen a nuestros dos países, desempeñándose su honroso cargo, con la más viva satisfacción de mi gobierno" ${ }^{57}$

\section{LA LARGA ESPERA}

Retomando el curso de la Colección, durante los meses que estuvo Levillier en Argentina, la propuesta se mantuvo latente, pero sin grandes avances. Seguramente para decidir si México apoyaría la propuesta, Puig avisó a la Secretaría en México sobre la situación de dicha colección a partir de la información obtenida en el diario La Nación: hasta la fecha el cici había aprobado la propuesta, encomendando al IICI que se creara un "comité de americanistas" que redactara el plan "científico y financiero", el cual sería sometido a aprobación en la siguiente asamblea en Ginebra. Varios gobiernos habían prometido financiamiento, pero aún no lo habían concretado. Por ello, Levillier habló con el embajador para pedirle que recordara al secretario que México había ofrecido que se incluirían en los próximos presupuestos 10 o 20000 pesos, comentándole que el gobierno argentino, por su parte, había ofrecido cooperar con 20000 pesos. Puig reitera su opinión negativa sobre el embajador argentino por su hispanofilia y asume que el mentado proyecto posiblemente

${ }^{56}$ AHSRE, 24-12-42, Padilla al srio. de Relaciones Exteriores, 24 de agosto de 1937.

57 AHSRE, 24-12-42, Cárdenas a Justo, 15 de febrero de 1938. 
"adolezca de parcialidad en el mismo sentido que las opiniones del mencionado embajador”. Por ello, si México decide apoyar "sería conveniente" que nombrara al historiador Carlos Pereyra para que se encargara de la parte de arqueología e historia de México. Pocos días después, telegrafió a México para comentar que, según Levillier, la cancillería argentina había instruído a su delegación en Ginebra para apoyar la moción de la publicación con financiamiento, por lo que rogaba a México que tomara una acción similar. La reacción de México no se hizo esperar, instruyendo de inmediato a sus delegados para que apoyaran la moción argentina ofreciendo cooperación económica a la Colección, mientras que avisaban a Puig que verían la forma en que quedaría integrado el comité que seleccionaría las obras. ${ }^{58}$

Por su parte, Marte R. Gómez, ministro de la legación de México en París y representante ante la SDN (1934-1936), comunicó que no existía ningún peligro de que la colección "adolezca de parcialidad en el mencionado sentido" porque el IICI integraría un grupo de especialistas de reconocida "seriedad científica" para su realización, entre ellos Gonzalo Zaldumbide (Ecuador), Ramón Menéndez Pidal (España), Paul Rivet (Francia), Francisco García Calderón (Perú), Parra Pérez (Venezuela) y Reygadas Vértiz y Alfonso Caso (México). Conoce bien el prestigio de éstos, en especial de Rivet, director del Museo de Etnografía del Trocadero, "de criterio político muy avanzado" (candidato de los intelectuales de izquierda para el Consejo Municipal de París). Por su parte, el ministro de Venezuela en Roma, Parra Pérez, es un distinguido "bolivariano" y por tanto

\footnotetext{
${ }^{58}$ AHSRE, III-538-5, Puig al srio. de Relaciones Exteriores, 3 de septiembre de 1935. La Nación, "En Ginebra tratarán el mes entrante una proposición argentina" (10 sep. 1935). Puig a Relaciones Exteriores, 14 de septiembre de 1935. Relaciones Exteriores a Puig, 17 de septiembre de 1935; el Oficial Mayor a delegación mexicana en Ginebra y delegación mexicana a Relaciones Exteriores (ambos telegramas), 18 de septiembre de 1935. Garrido a Puig, 24 de septiembre de 1935.
} 
opuesto a lo "hispanófilo". Agrega que considera importante participar de dicha colección debido a los recientes hallazgos arqueológicos de Monte Albán. Por último, anexa la lista de historiadores y etnólogos que considera el IICI para la Colección.59

Tras haber tomado la medida, la Secretaría de Relaciones Exteriores se comunicó con su par en Educación Pública para recordarle que en julio de ese año Levillier había tratado con el secretario sobre la colaboración financiera de nuestro país para la publicación y traducción al inglés o al francés de una obra original e inédita de un autor de cualquier nacionalidad, sobre algún tema de arqueología, etnografía, lingüística, geografía, geología o historia mexicana. Solicitó que se incluyera en el presupuesto de esta secretaría para el próximo año el recurso correspondiente..$^{60}$

La prensa bonaerense que cubría las noticias de la Sexta Asamblea de la SDN en Ginebra aclaró al respecto que si bien aprobó el proyecto de Levillier éste quedó a la espera de que los gobiernos e instituciones científicas contribuyeran a su financiamiento. Además, instruyó a la cicı para que formara un comité de especialistas que dirigieran la obra al elaborar un nuevo plan "bajo su propia responsabilidad", es decir, con libertad en su trabajo para orientarla según su propio criterio y no el de Levillier exclusivamente (aunque formará parte del mismo). Esto agradó al embajador, quien mantuvo su temor de que el criterio "antiindio" del argentino hiciera que en la colección se justificaran los

59 AHSRE, III-538-5, Gómez al sub. srio. de Relaciones Exteriores, 21 de octubre de 1935. Dicha carta es reenviada para su conocimiento a Puig, AHSRE, III-538-5, Garrido al embajador de México en Buenos Aires, 16 de noviembre de 1935, anexando poco después la lista de expertos encargados. Sierra al embajador de México en Argentina, 3 de diciembre de 1935.

60 AHSRE, III-538-5, Ceniceros al srio. de Educación Pública, 18 de septiembre de 1935. Con el fin de saber cuál era el monto del apoyo, se comunican nuevamente con el ministro de México en París para saber su opinión. AHSRE, III-538-5, Garrido al ministro de México en París, 16 de noviembre de 1935. 
actos "de crueldad" de los españoles en América. Sin embargo, Puig mantuvo una guardia precautoria. ${ }^{61}$

Un mes después, desde París, el ministro informó de sus últimas averiguaciones: la publicación de éstas se realizaría sólo mediante subvenciones nacionales para contribuir a toda la colección o sólo para publicar los libros correspondientes a la historia de sus países. Esto significaba que el plan de Levillier, presentado en 1934, había sido revisado por los expertos que asignó la CICI, quienes decidieron que era un proyecto demasiado vasto (tanto por su número como por los temas), decidiendo que con 15 o 20 volúmenes sería suficiente para dar al "público europeo una idea precisa, clara y completa de la evolución histórica que se pretende resumir". Por el momento, estaban estudiando la organización de éstos, por lo que no se podía determinar cuántos volúmenes serían para cada país. ${ }^{62}$

El año 1936 parecía terminar sin mayores avances para la colección, pese a que la Asamblea de la SDN solicitó en su reunión que se constituyera de inmediato un comité de expertos para realizar un estudio financiero, un plan definitivo y un programa de ejecución..$^{63}$ A su vez, la Conferencia para el Mantenimiento de la Paz y seguridad reunida en Buenos Aires (diciembre) recomendó a los gobiernos latinoamericanos apoyar la colección. ${ }^{64}$

Desde Argentina, Antonio Aita y Ricardo Levene, de la Comisión Nacional de Cooperación Intelectual, intentaron presionar para conseguir adhesiones. El tema fue puesto a consideración en el II Congreso de Historia de América (Buenos

${ }^{61}$ AHSRE, III-538-5, Puig al srio. de Relaciones Exteriores, 22 de octubre de 1935. La Nación, "Repercusión en Ginebra de una iniciativa del Dr. Levillier", 22 de octubre de 1935. De Puig al srio. de Relaciones Exteriores (21 dic. 1935). 62 AHSRE, III-538-5, Gómez al srio. de Relaciones Exteriores, 21 de enero de 1936. La información es remitida a la SEP el 22 de febrero de 1936.

${ }^{63}$ AU, IICI, DD.X.6, s.f.

64 Pernet, "The spirit of harmony", p. 146. 
Aires, julio de 1936) y, tras ser aprobado por unanimidad, se solicitó a todas las sociedades de estudios históricos, arqueológicos y geográficos del continente que expresaran su opinión y su adhesión al plan aprobado por el Instituto de la Colección Etnográfica e Histórica de América. ${ }^{65}$

Por su parte, la Facultad de Filosofía y Letras de la Universidad de Buenos Aires le aseguró a México que costearía la edición de la colección en español, por lo que solicitaban su apoyo. Para poder dar una respuesta, la Secretaría de Relaciones Exteriores le escribió a la de Educación Pública para recordarles que ellos habían acordado apoyar desde hacía tiempo la colección y que la delegación había ofrecido ayuda económica en la Asamblea de la SDN. Aprovechan la ocasión para recordar que es necesario que le prestan atención a la Comisión Mexicana de Cooperación Intelectual (que dependía de dicha Secretaría), en particular en las obras de las dos colecciones: la mencionada de Levillier y la Colección Hispanoamericana (Iberoamericana), que ya llevaba publicados varios textos de otros países de la región. Sería aconsejable que se tomase una decisión para evitar los comentarios de críticos y lectores que verían con sorpresa que el gobierno mexicano siguiera sin una justificación por no participar. ${ }^{66}$

Antes de finalizar el año, la Secretaría de Educación Pública respondió parcialmente al manifestarse por la publicación de Cantares mexicanos (la cual acababa de ser traducida de lengua mexicana al español) y de la obra literaria El Periquillo Sarniento, del Pensador Mexicano; ambas obras deberían ser traducidas al francés. Si Relaciones Exteriores estaba de acuerdo con la propuesta se procedería a financiar la publicación de las obras

${ }_{65}$ AU, IICI, DD.X. 6, Antonio Aita a Ricardo Levene 18 de febrero de 1937 y Antonio Aita a Henri Bonnet, 16 de julio de 1937.

${ }_{66}$ AHSRE, III-538-5, el encargado de negocios al srio. de Relaciones Exteriores, 29 de septiembre de 1936. Beteta al srio. de Educación Pública, 5 de octubre de 1936. Memorándum, departamento diplomático a la SEP, 9 de octubre de 1936. Reiteran la solicitud el 15 de diciembre de 1936. 
aludidas. ${ }^{67}$ La Secretaría hizo notar un error importante: de las dos obras aludidas sólo la primera podía ser propuesta para la Colección de Etnografía e Historia sugerida por Levillier. La segunda de ellas, dado que es una novela, debería sugerirse para la participación de México en la Colección Iberoamericana, la cual nada tenía que ver con la mencionada. La suma que otorgarían para la impresión de la segunda sería de 15 o 20000 francos, mientras que para la primera no se arriesgan a decir un monto puesto que lo importante por el momento era transmitir que iban a participar con tres o cuatro volúmenes (entre ellos el de Cantares mexicanos mencionado). ${ }^{68}$

La aprobación llegó poco después, pero difería de la propuesta original. Como informó la Comisión Mexicana de Cooperación Intelectual, se integraría un comité de especialistas en arqueología, historia y etnografía en el país para estudiar la propuesta original, hacer los cambios necesarios y escribir los volúmenes. El control quedaría por completo en México, aunque la colección siguiera bajo la dirección de Levillier. ${ }^{69}$ Los especialistas fueron Enrique Juan Palacios (del Departamento de Monumentos de la Sección de Arqueología de la Secretaría de Educación Pública), Silvio Zavala (del Departamento de Monumentos de la Sección de Historia de la Secretaría de Educación Pública) y Ezequiel Chávez (de la Sociedad Científica Antonio Alzate). Éstos remitieron a Alfonso Reyes, secretario de la Comisión Mexicana de Cooperación Intelectual, sus comentarios del proyecto. A Palacios le preocupaba que, dados los numerosos volúmenes y la gran cantidad de materias contenidas,

\footnotetext{
${ }^{67}$ AHSRE, III-538-5, el oficial mayor de la SEP al srio. de Relaciones Exteriores, 26 de diciembre de 1936.

68 AHSRE, III-538-5, Beteta al srio. de Educación Pública, 1o de febrero de 1937.

${ }^{69}$ AHSRE, III-538-5, Sánchez Pontón al srio. de Relaciones Exteriores, 27 de febrero de 1937; Hidalgo a Sánchez Pontón y Depto. Diplomático a Levillier, 4 de marzo de 1937.
} 
fuera necesario un centenar de especialistas para alcanzar la claridad esperada. Por ello, el director de Monumentos Prehispánicos consideraba que deberían limitarse a recomendar que se publicaran sólo trabajos que estuvieran muy adelantados o concluidos, para lo que sugería varios títulos de arqueología mexicana del Tajín, Cholula, Chichen Itzá, Palenque, Xochicalco, trabajos que en poco tiempo podría tener listos.

Para Chávez era incorrecto que se dedicara sólo a los orígenes (siglos XV al XVII), dado que era indispensable pensar en una unidad continental, la cual recién había sido alcanzada en la Conferencia Interamericana para el Mantenimiento de la Paz (diciembre de 1936). Citando al subsecretario de Estado de Estados Unidos, Summer Welles, insistía en que esta reunión era de vital importancia pues señalaba el momento histórico en que se cerraba un capítulo y se abría otro en las relaciones interamericanas, uno en el que hay mayor acercamiento por compartir formas de "gobierno democrático" e ideales. Por ello el proyecto debería llamarse Colección Etnográfica e Histórica, cuyo fin sería el estudio de la civilización americana desde sus orígenes hasta la Conferencia Interamericana (1936). Puesto que el periodo se ampliaría enormemente, debía dividirse en tres categorías: la precolombina (culturas indígenas), la colombina (colonial, antes de las naciones independientes) y desde que son naciones hasta 1936. Consideraba también que la colección debería reeditar obras anteriores y que -siguiendo el modelo de las universidades de Francia- se sometiera cada volumen a publicarse a la aprobación de una comisión técnica, un revisor $\mathrm{y}$ un corrector.

Por su parte, Zavala realizó una evaluación puntual examinando la propuesta desde un aspecto histórico para sugerir: modificar el orden de varios volúmenes, agrupar algunos otros (como el de expediciones e ideología de la conquista), agregar el estudio económico de la Iglesia (para tratar el tema de las obvenciones), dar autonomía al estudio de las encomiendas y 
extender el estudio sobre el derecho español en las Indias. Para ello sugirió que se invitara a escribir a los especialistas en la conquista: José López Portillo, Rafael García Granados, Ignacio Rubio Mañé y Lewis Hanke. Para la época colonial recomendó a Rafael Heliodoro Valle, Federico Gómez de Orozco, Manuel Toussaint, Joaquín Ramírez Cabañas, Alberto Carreño, Mariano Cuevas, Robert Ricard, Frances V. Scholes, H. I. Priestley (y el propio Zavala)..$^{70}$

Mientras tanto, el dinero para la colección (25000 pesos mexicanos) seguía sin ser depositado y la copia del acuerdo firmado por el presidente tampoco era enviado al IICI en París. Esta situación preocupaba a la cancillería porque en los próximos días se reuniría en París la II Conferencia General de las Comisiones Nacionales de Cooperación Intelectual. El delegado por México, Isidro Fabela, tendría que dar razón de esto, por lo que solicitaba que enviaran la copia correspondiente del decreto. A esto responde la Comisión Mexicana de Cooperación Intelectual aclarando que faltaba la firma del presidente y de la propia Secretaría de Educación, pero que podía comunicarse la decisión al IICI. Esto se transmitió de inmediato a Fabela junto con las opiniones de los especialistas mexicanos y al gobierno argentino, para su tranquilidad. ${ }^{71}$

70 AHSRE, III-538-5, Palacios a Alfonso Reyes, 13 de mayo de 1937. Zavala a Reyes, 8 de junio de 1937. Chávez a Reyes, 12 de junio de 1937. Esto fue enviado a la Secretaría pocos días después (24 de junio). Una síntesis de estas evaluaciones se envió a París para informar al IICI. AU, IICI, DD.X.6, de Alfonso Reyes a Henri Bonnet, 17 de junio de 1937.

71 AHSRE, III-538-5, Tejeda a Relaciones Exteriores, 2 de junio de 1937, Hidalgo al srio. de Educación Pública, 4 de junio de 1937, srio. de Relaciones Exteriores al srio. de Educación Pública, 11 de junio de 1937, Reyes a srio. de Relaciones Exteriores, 17 de junio de 1937, Vázquez Vela al srio. de Relaciones Exteriores, 24 de junio de 1937, depto. Diplomático a Fabela, y depto. Diplomático al encargado de negocios de Argentina en México, 28 de junio de 1937. Hidalgo a Reyes, 3 de julio de 1937. Hidalgo a Fabela, 16 de julio de 1937. 
Durante el mencionado acto de París se reunió el comité de expertos que había nombrado el IICI para dar seguimiento a la colección: Levillier, Rivet, Francisco García Calderón, Luis Valcárcel (director del Museo Nacional de Arqueología de Lima), José Núñez y Domínguez (subdirector del Museo Nacional de Historia de México) y Waldo Leland (historiador y miembro del CNCI de Estados Unidos). Este grupo decidió que la serie sobre civilización americana antes de la llegada de los españoles podría iniciarse apenas se tuvieran los recursos y que la del periodo colonial fuera pospuesta. Esto significó un gran golpe para Levillier, quien redobló sus esfuerzos para conseguir dinero. ${ }^{72}$

Para concretar este otro plan más acotado, Leland, miembro de la American Council of Learned Societies, sugirió que el proyecto debería estar bajo el control del Comité Internacional de Ciencias Históricas y el Instituto Panamericano de Geografía e Historia (IPGH). Le parecía preocupante que, aunque el proyecto siguiera en la agenda del IICI, no se hubiera hecho ningún comentario al respecto en la Asamblea del año anterior. ${ }^{73} \mathrm{La}$ propuesta del estadounidense no fue apoyada por su país porque el historiador americanista Herbert Bolton no respondió al llamado de Levillier (pese a haber sido considerado uno de los autores de un volumen) debido a que por ese entonces intentaba promover otro tipo de libro de texto (relacionado con la política de la buena vecindad que impulsaba el presidente Roosevelt), en el cual prevaleciera la noción de que las repúblicas americanas compartían una historia común. Gran Bretaña se negó también -en alianza con esta respuesta-, considerando que el plan era demasiado ambicioso y que, además, esto rehabilitaría el colonialismo español. ${ }^{74}$

72 Pernet, “The spirit of harmony", p. 147.

73 AU, IICI, DD.X.6, Waldo G. Leland a Margarete Rothbarth, 22 de junio de 1936.

74 Pernet, “The spirit of harmony", pp. 142-143. Herbert E. Bolton (1870-1953) fue un historiador importante para las relaciones culturales 
Pese a esto, Isidro Fabela, representante de México ante la Sociedad de Naciones, informó al Instituto que en la última asamblea (octubre de 1937) los delegados mexicanos anunciaron que su gobierno tenía la intención de contribuir con la Colección Etnográfica e Histórica con un monto de 25000 pesos mexicanos a partir de 1938, gesto que agradece enormemente el director, pero solicita que sea más específico respecto a cuándo se depositaría ese dinero porque sin esos recursos sería imposible iniciar los trabajos. ${ }^{75}$ Sin embargo, no se depositó la suma acordada, por lo que comenzó a correr el rumor de que México suspendería el pago ofrecido. La situación era comprometedora para la delegación mexicana en Ginebra por lo que Cancillería indagó. La respuesta fue que no se suspendería y que el siguiente año (1939) se haría efectiva, pero esto nunca sucedió. ${ }^{76}$

En la Conferencia Panamericana, reunida en Lima en diciembre de 1938, volvió a surgir la proposición, dando su aprobación todos los países, pero ante la falta de apoyos financieros concretos y la situación política mundial, el gobierno argentino

interamericanas. Afirmaba que el continente tenía una unidad histórica tal como Europa tenía la suya, por lo que se ocupó de concebirla como una historia total desde el polo norte hasta el sur desde los días de Colón a la actualidad. Véase De Onís, "The Americas of Herbert E. Bolton"; Magnaghi, Herbert E. Bolton.

75 AU, IICI, DD.X.6, de Isidro Fabela a Henri Bonnet, 30 de agosto de 1937 y de Henri Bonnet a Isidro Fabela, 23 de octubre de 1937. Fabela aprovechó para expresar su extrañeza sobre por qué México no tiene más obras en la Colección Iberoamericana, dado que a la fecha se han publicado las siguientes: Historias chilenas, El diamante del Brasil, Bolivar, Facundo, América, Casimiro, Ensayos, Mis montañas, Tradiciones peruanas, La mulata, Teatro, y un volumen de Folklore chileno. AHSRE, Isidro Fabela a Luis Sánchez Pontón, París, 23.VIII.1937, exp. III-544-4.

76 AHSRE, III-538-5, Tello a Relaciones Exteriores, 20 de septiembre de 1938, Hidalgo a Secretaría Educación Pública, 21 de septiembre y 6 de octubre, de la Secretaría Educación Pública a la de Relaciones Exteriores, 7 de octubre, de Relaciones Exteriores a Delegación Permanente en Ginebra, 15 de octubre de 1938. 
decidió solicitar, en octubre de 1938, la devolución del monto que había depositado ante la imposibilidad de realizarlo. ${ }^{77}$ Pese a esto, la Primera Conferencia de Comisiones Americanas de Cooperación Intelectual, realizada en Santiago de Chile en enero de 1939, puso en su agenda el proyecto de colección histórica y etnográfica americana, el cual -explicaba-, se encontraba detenido por el inicio de la guerra, pero esperaban que se reanudara cuando París fuera liberado. ${ }^{78}$

\section{CONCLUSIÓN}

El proyecto de Levillier nunca se concretó, aunque en Argentina el historiador Ricardo Levene publicó en 1940 una Historia de América de varios tomos y con varios autores en español, inglés y portugués. De manera sintética e ilustrativa mostraban, sin entrar en debates sobre la leyenda blanca o negra, el estar "ceñida a la verdad histórica", pero sin caer en la "disquisición erudita”. La coyuntura histórica era importante para Levene al permitir mostrar el grado de civilización y cultura de América, el cual contrastaba con la conmoción en Europa por el inicio de la guerra. Ese "nuevo mundo" había alcanzado su "momento de esplendor" cuando el resto del mundo parecía sumirse nuevamente en el caos. ${ }^{79}$ Entre los muchos colaboradores de

77 El Instituto envió 1400 cartas a instituciones académicas para ofrecer suscripciones a la colección, monto con el cual asegurarían el recurso para su publicación. Sin embargo, pese a que pidieron a los delegados que aseguraran la suscripción de cada uno de sus gobiernos, sólo se consiguieron 50 suscripciones. La esperanza recayó en que los gobiernos más interesados, como España, financiaran el faltante, pero como ésta entró en una guerra civil en 1936, fue imposible. Pernet, “The spirit of harmony”, pp. 146-147.

78 AHSRE, La comisión chilena a la comisión mexicana, Santiago de chile, 16. V. 1938, exp. III-1707-6. WALKer Linares, Cooperación intelectual, pp. 11 y 18.

79 En 1940, el historiador argentino Ricardo Levene publicó su versión de La historia de América en 14 tomos, con la editorial privada W. M. Jackson Inc., 
esa colección no se encontraba Levillier, quien fungía entonces como embajador en Uruguay y que poco después se retiraría de la diplomacia para dedicarse a la investigación histórica. ${ }^{80}$

¿Por qué esta colección prosperó y la otra no? La primera respuesta es la más evidente y tiene que ver con el financiamiento: la de Levene fue publicada por una editorial comercial, eran menos volúmenes (14 vs 33 propuestos por Levillier) y no buscó apoyo gubernamental de varios países, ni mucho menos de organismos internacionales. La segunda se relaciona con la temporalidad: la propuesta se centraba sólo en los siglos XV al XVII, mientras la concretada abarcaba desde el periodo precolombino hasta sus días, todo de manera resumida por países y con muchas ilustraciones. Con ello, la polémica en torno a la conquista quedó diluida en una continuidad histórica donde se entrelazaba con la independencia, la organización de los estados nacionales y su actualidad panamericana (más que con el pasado hispanoamericano).

Tras lo expuesto en este artículo, es evidente que el debate en torno a la propuesta de Levillier no radicaba en su calidad académica, sino en aquellos aspectos de política internacional que implícitamente tocaba. Para Argentina, era una manera de marcar su presencia en el comite Internacional de Cooperación Intelectual y, a través de esto, en la sDN. Indirectamente, le fue útil para acercarse a España y a México. Su apoyo, empero, no

una colección de 14 volúmenes que abarcaba desde antes del descubrimiento hasta la actualidad, realizada por historiadores especializados, la mayor parte argentinos y otros del continente (ningún europeo). La misma fue publicada en español, inglés y portugués (traducciones de Roberto Rauffet y Benjamín de Garay). Levene, Historia de América, pp. xi-xv.

80 A fines de 1941 le ofrecen regresar como embajador del Perú, pero Levillier decide retirarse para dedicarse a la investigación histórica. Años después fue nombrado director del Instituto del Servicio Exterior de la Nación, cargo que desempeñó de 1963 a 1964, cuando renunció por desavenencias con la reglamentación del servicio exterior y del instituto. Murió en 1969. KaTZENSTEIN, Roberto Levillier, p. 24. 
fue decisivo: las numerosas cartas de Levillier para lograr encontrar apoyo entre los otros países permiten ver que, salvo por el apoyo de la Comisión de Cooperación Intelectual de Argentina, el gobierno se mantuvo a la espera. Entre otras cosas, esto se relacionó con el affaire en el que se vio envuelto Levillier, el cual pone de manifiesto otro tipo de tensiones en su país que tenían que ver con el contexto político de la década infame cuando el antisemitismo y el nacionalismo más conservador ganaban espacio en los medios.

México estuvo particularmente atento a este proceso no sólo para saber si se realizaría un cambio de embajador argentino en México, o porque le urgiera realizar el aporte económico que habían, prometido para solventar la colección. La vigilancia de los embajadores mexicanos, en especial de Puig, se centró en dos aspectos. El primero se derivaba de los comentarios que hacía Levillier sobre el México actual, postrevolucionario, el presidente Cárdenas y la posición que ocupaba este país en los debates internacionales. No confiaban en que las opiniones emitidas por el embajador transmitieran la representación que ellos querían: un país fuerte, vigoroso, que había dejado atrás la parte sanguinaria de la revolución y se abanderaba en sus principios para un progreso social. Además, lo que el país requería y estaban conscientes de que, en Buenos Aires, la recepción podía ser interpretada por grupos radicalizados que temían que el socialismo a la mexicana se extendiera a su país por medio de intercambios intelectuales.

El segundo, aparentemente relacionado con el debate académico, se relacionaba con el hispanismo a ultranza de Levillier y su defensa de la conquista española en América mediante la propuesta de una colección que, a todas luces, revaloraría esa España católica y tradicional de la cual México se distanciaría políticamente al tomar partido por la República y defenderla en la SDN. ${ }^{81}$ Como era de imaginar, aunque se hablara del tiempo

${ }^{81}$ Sánchez y Herrera, Contra todo. 
pasado, histórico, el debate político se tiñó de un presente en el cual el acercamiento hispanomexicano era interpretado por los actores según se identificaran con los contendientes de la guerra civil española. Aunque ésta no fue mencionada, es identificable el temor del embajador mexicano en Buenos Aires de que sectores hispanistas (conservadores) alabaran a Levillier y que, de realizarse la colección como se había propuesto, se reivindicara un hispanismo conservador que olía a franquismo. Por ello, aunque se pidió la opinión de especialistas, México prometió apoyar siempre y cuando se modificara radicalmente la colección, financiando las obras que el país consideraba representativas. La cancillería mexicana no se preguntó si la corriente de interpretación de Levillier coincidía con la de Zavala (basada en un cientificismo que defendía la imparcialidad basada en la confrontación de numerosos documentos) ${ }^{82}$ porque no se trataba de un debate historiográfico, sino más bien de resolver un problema político de países latinoamericanos preocupados y ocupados en alcanzar una dimensión internacional.

\section{SIGLAS Y REFERENCIAS}

CA-INBA Capilla Alfonsina-Instituto Nacional de Bellas Artes, Ciudad de México, México.

AU Archivo Unesco.

BNDCH Biblioteca Nacional Digital de Chile.

AHSRE Archivo Histórico Secretaría de Relaciones Exteriores, Ciudad de México, México.

CaIllet-Bois, Ricardo, "Roberto Levillier”, en Revista Historia de América, 71 (ene.-jun. 1971), pp. 156-160.

82 En México esta corriente tradicional fue dominante hasta 1930 (con Zavala a la cabeza), cuando apareció otro grupo lidereado por O’Gorman, quien disputó un lugar en la profesionalización del campo de la historia (en vías de institucionalizarse) defendiendo el historicismo. Véase Moctezuma, El camino de la historia. 
Connejo, Atilio, Levillier, historiador de América, Salta, Instituto de San Felipe y Santiago de Estudios Históricos de Salta, 1952.

De Onís, José, “The Americas of Herbert E. Bolton”, en The Americas, 12: 2 (oct. 1955), pp. 157-168.

Dumont, Juliette, L'Institut International de Coopération Intellectuelle et le Brésil (1924-1946). Le Pari de la Diplomatie Culturelle, París, l'IHEALCreda, 2008.

Dumont, Juliette, "De la coopération intellectuelle à la diplomatie culturelle. Les voies/x de l'Argentine, du Brésil et du Chili (1919-1946)", tesis de doctorado en historia, París, Université Sorbonne Nouvelle, 2013.

Escudé, Carlos y Andrés Cisneros, Historia de las Relaciones Exteriores Argentinas, http://www.argentina-rree.com/historia.htm

Herrera, Fabián, “México y el Instituto Internacional de Cooperación Intelectual, 1926-1939”, en Tzintzun, 49 (ene.-jun. 2009), pp. 169-200.

Herrera, Fabián, México en la Sociedad de Naciones, 1931-1940, México, Secretaría de Relaciones Exteriores, 2014.

Herrera, Fabián y Yannick Wehrli (coords.), América Latina y el internacionalismo ginebrino de entreguerras: implicaciones y resonancias, México, Secretaría de Relaciones Exteriores y Universidad Michoacana San Nicolás de Hidalgo [en prensa].

Katzenstein, Juan Carlos, Roberto Levillier, Buenos Aires, Consejo Argentino para las Relaciones Internacionales, Los Diplomáticos, núm. 4, octubre de 1993.

Kolasa, Jan, International Intellectual Cooperation: The League Experience and the Veginnings of UNESCO, Breslavia, Laklad Narodowy im. Ossolinskich, 1962.

Levene, Ricardo, Historia de América, Buenos Aires, W. M. Jackson Inc., 1940.

Levillier, Roberto, La reconstrucción del pasado colonial, Buenos Aires, Librería Mendesky, 1917. 
Magnaghi, Russel M., Herbert E. Bolton and the historiography of the Americas, Westport, Connecticut, London, Greenwood Press, 1998.

Mc Pherson, Alan y Yannick Wehrli (eds.), Beyond Geopolitics: Latin America at the League of Nations, University of New Mexico Press, 2015.

Moctezuma Franco, Abraham, "El camino de la historia hacia su institucionalización”, en Historia y Grafía, 25 (2005), pp. 45-78.

Ortemberg, Pablo, "Geopolítica de los monumentos: los próceres en los centenarios de Argentina, Chile y Perú (1910-1924)”, en Anuario de Estudios Americanos, $72: 1$ (ene.-jun. 2015), pp. 321-350.

Pagano, Nora y Martha Rodríguez, "Las polémicas historiográficas en el marco de la profesionalización y consolidación de la disciplina histórica", en Estudios Sociales, Revista Universitaria Semestral, año IX, 17 ( $2^{\circ}$ semestre 1999), pp. 35-47.

Palacios, Guillermo y Ana Covarrubias, Historia de las relaciones internacional de México, 1821-2010, Mercedes de Vega coordinadora, vol. 4 América del Sur, México, Secretaría de Relaciones Exteriores, 2011.

Pernet, Corinne, "The spirit of harmony. The politics of (Latin American). History at the League of Nations", en Mc Pherson y Wehrl (eds.), 2015, pp. 135-153.

Pita, Alexandra, Educar para la paz. México y la cooperación intelectual, internacional. México, Secretaría de Relaciones Exteriores, Universidad de Colima, 2014.

Pita, Alexandra, "América [Latina] en París. Mistral, Reyes y Torres Bodet en la Colección Iberoamericana 1927-1940”, en Herrera y WeHrLi (coords.) [en prensa].

Real Academia de la Historia, "Premio hispano-americano para la Fiesta de la Raza”, en Boletín de la Real Academia de la Historia, octubre de 1920.

RenOliet, Jean Jaques, UNESCO oubliée. La Societé des Nations et la coopération intellectuelle (1919-1946), París, Publications de la Sorbonne, 1999.

Sánchez, Agustín y Fabián Herrera, Contra todo y contra todos. La diplomacia mexicana y la cuestión española en la Sociedad de Naciones, 1936-1939, Santa Cruz de Tenerife, Las Palmas de Gran Canaria, Ediciones Idea, 2011. 
Walker Linares, Francisco, Cooperación intelectual, Santiago de Chile, Comisión Chilena de Cooperación Intelectual, 1943.

Wehrli, Yannick, "New Histories of Latin America at the League of Nations”, en Mc Pherson y Wehrli (eds.), 2015, pp. 1-20.

Zavala, Silvio, reseña de Historia de la Leyenda Negra Hispano-Americana, en Revista de Historia de América, 16 (dic. 1943), pp. 149-151.

Zuleta, María Cecilia, “Alfonso Reyes y las relaciones México-Argentina: Proyectos y realidades, 1926-1936”, en Historia Mexicana, xLv: 4 (180) (abr.jun. 1996), pp. 867-905. 
Anexo 1

PROPUESTA DE AUTORES Y VOLÚMENES, ROBERTO LEVILLIER (1934)

\begin{tabular}{|c|c|c|c|}
\hline Autores propuestos & Pais & Cargo/profesión & Volumenes \\
\hline Roberto Levillier & Argentina & $\begin{array}{l}\text { Historiador y } \\
\text { diplomático } \\
\text { (embajador de } \\
\text { argentina en México } \\
\text { y delegado de la SDN) }\end{array}$ & $\begin{array}{l}\text { Descubrimiento y } \\
\text { organización de } \\
\text { Charcas (Bolivia), } \\
\text { Argentina y el } \\
\text { Paraguay en } \\
\text { el siglo XvI }\end{array}$ \\
\hline Ricardo Levene & Argentina & $\begin{array}{l}\text { Historiador, } \\
\text { presidente de la U. } \\
\text { de la Plata }\end{array}$ & $\begin{array}{l}\text { Leyes y ordenanzas } \\
\text { destinadas a indígenas } \\
\text { y su aplicación en el } \\
\text { siglo xvI }\end{array}$ \\
\hline Juan B. Terán & Argentina & $\begin{array}{l}\text { Rector de la } \\
\text { Universidad } \\
\text { de Tucumán } \\
\text { en Argentina, } \\
\text { historiador y filósofo }\end{array}$ & $\begin{array}{l}\text { La Iglesia y el Estado } \\
\text { en América en el } \\
\text { siglo xvI }\end{array}$ \\
\hline Rómulo D. Carbia & Argentina & $\begin{array}{l}\text { Profesor Universidad } \\
\text { de La Plata, } \\
\text { especialista en Colón }\end{array}$ & $\begin{array}{l}\text { Los descubrimientos } \\
\text { de Colón y sus } \\
\text { compañeros }\end{array}$ \\
\hline Henri Pirenne & Bélgica & Historiador eminente & $\begin{array}{l}\text { Las villas industriales de } \\
\text { Europa en el siglo xvI }\end{array}$ \\
\hline Toledo & Brasil & $\begin{array}{c}\text { Autor de numerosas } \\
\text { obras de la época }\end{array}$ & $\begin{array}{l}\text { Descubrimiento y } \\
\text { fundación de Brasil }\end{array}$ \\
\hline $\begin{array}{l}\text { Washington A. } \\
\text { Burpee }\end{array}$ & Canadá & Especialista en el tema & $\begin{array}{l}\text { Descubrimientos de } \\
\text { Cartier y fundación } \\
\text { francesa en Canadá, } \\
\text { siglo xvI }\end{array}$ \\
\hline Raimundo Rivas & Colombia & $\begin{array}{l}\text { Presidente de la } \\
\text { Academia de la } \\
\text { Historia de Bogotá }\end{array}$ & $\begin{array}{l}\text { Balboa y la conquista } \\
\text { del pacífico }\end{array}$ \\
\hline Rafael Restrepo & Colombia & Historiador & $\begin{array}{l}\text { Giménez de Quesada } \\
\text { y los fundadores de } \\
\text { Bogotá }\end{array}$ \\
\hline
\end{tabular}


Anexo 1

PROPUESTA DE AUTORES Y VOLÚMENES (continúa)

\begin{tabular}{|c|c|c|c|}
\hline Autores propuestos & Pais & Cargo/profesión & Volumenes \\
\hline Ricardo Donoso & Chile & $\begin{array}{l}\text { Soc. Chilena de } \\
\text { Historia y Geografía }\end{array}$ & $\begin{array}{l}\text { Almagro y Valdivia en } \\
\text { Chile }\end{array}$ \\
\hline $\begin{array}{l}\text { Jacinto Jijón } \\
\text { y Caamaño }\end{array}$ & Ecuador & $\begin{array}{l}\text { "Uno de los mejores } \\
\text { americanistas" }\end{array}$ & $\begin{array}{l}\text { Los cronistas de indias } \\
\text { en el siglo xvI }\end{array}$ \\
\hline C. Bayle & España & $\begin{array}{l}\text { "Sacerdote que ha } \\
\text { publicado sobre el } \\
\text { tema" }\end{array}$ & $\begin{array}{l}\text { Las Casas, el hombre, } \\
\text { el apóstol y el } \\
\text { historiador }\end{array}$ \\
\hline P.B.V.Heredia & España & $\begin{array}{l}\text { "Ha dictado } \\
\text { conferencias en } \\
\text { la Universidad de } \\
\text { Salamanca sobre } \\
\text { el tema y está } \\
\text { calificado" }\end{array}$ & $\begin{array}{l}\text { Los justos títulos de } \\
\text { los reyes de España } \\
\text { sobre las Indias y } \\
\text { las concepciones del } \\
\text { padre Vitoria }\end{array}$ \\
\hline Rafael Altamira & España & $\begin{array}{l}\text { Prof. Universidad de } \\
\text { Madrid, historiador } \\
\text { y miembro del } \\
\text { Tribunal de La Haya }\end{array}$ & $\begin{array}{l}\text { Estado político de } \\
\text { Europa en los } \\
\text { siglos xv y xvI }\end{array}$ \\
\hline $\begin{array}{l}\text { Ramón Menéndez } \\
\text { Pidal }\end{array}$ & España & $\begin{array}{l}\text { Prof. Fac. Filosofía de } \\
\text { Madrid, presidente } \\
\text { de la Academia de } \\
\text { la Lengua Española, } \\
\text { director del Centro } \\
\text { de Estudios } \\
\text { Históricos }\end{array}$ & $\begin{array}{l}\text { Cortés y Bernal Díaz } \\
\text { del Castillo }\end{array}$ \\
\hline Ballesteros & España & $\begin{array}{l}\text { Profesor Fac. Filosofía } \\
\text { de la Universidad de } \\
\text { Madrid }\end{array}$ & $\begin{array}{l}\text { El Estado de la España } \\
\text { del siglo xvI }\end{array}$ \\
\hline Lewis Hanke & $\begin{array}{l}\text { Estados } \\
\text { Unidos }\end{array}$ & $\begin{array}{l}\text { Ha trabajado en } \\
\text { la Biblioteca } \\
\text { Nacional de Madrid } \\
\text { (manuscritos) }\end{array}$ & $\begin{array}{l}\text { Los indígenas en las } \\
\text { encomiendas y } \\
\text { las minas }\end{array}$ \\
\hline
\end{tabular}


Anexo 1

PROPUESTA DE AUTORES Y VOLÚMENES (continúa)

\begin{tabular}{|c|c|c|c|}
\hline Autores propuestos & País & Cargo/profesión & Volúmenes \\
\hline H. E. Bolton & $\begin{array}{l}\text { Estados } \\
\text { Unidos }\end{array}$ & $\begin{array}{l}\text { Prof. Universidad de } \\
\text { Berkley }\end{array}$ & $\begin{array}{l}\text { Ensayos de } \\
\text { colonización de } \\
\text { ingleses en América } \\
\text { antes del Mayflower }\end{array}$ \\
\hline $\begin{array}{l}\text { Philip Ainsworth- } \\
\text { Means }\end{array}$ & $\begin{array}{l}\text { Estados } \\
\text { Unidos }\end{array}$ & $\begin{array}{l}\text { Escritor de numerosos } \\
\text { trabajos del tema }\end{array}$ & $\begin{array}{c}\text { Francisco, Bernardo y } \\
\text { Gonzalo Pizarro }\end{array}$ \\
\hline Robert Ricard & Francia & $\begin{array}{l}\text { Consagrado al estudio } \\
\text { de las órdenes } \\
\text { religiosas }\end{array}$ & $\begin{array}{l}\text { Organización y obra de } \\
\text { las órdenes religiosas } \\
\text { en las Indias en el } \\
\text { siglo XVI }\end{array}$ \\
\hline Henri Hauser & Francia & Prof. la Sorbona & $\begin{array}{l}\text { Influencia del } \\
\text { descubrimiento de } \\
\text { América del Sur en la } \\
\text { economía europea del } \\
\text { siglo XVI }\end{array}$ \\
\hline Louis Baudin & Francia & $\begin{array}{l}\text { Prof. Universidad de } \\
\text { Dijon }\end{array}$ & $\begin{array}{l}\text { El comercio y el } \\
\text { contrabando en las } \\
\text { Indias en el siglo XVI }\end{array}$ \\
\hline $\begin{array}{l}\text { R.B. Cuningham } \\
\text { Graham }\end{array}$ & $\begin{array}{l}\text { Gran } \\
\text { Bretaña }\end{array}$ & $\begin{array}{l}\text { Publicó numerosos } \\
\text { trabajos sobre el } \\
\text { tema }\end{array}$ & $\begin{array}{l}\text { Hawkins, Drake y los } \\
\text { grandes corsarios del } \\
\text { siglo XVI }\end{array}$ \\
\hline N. Politis & Grecia & $\begin{array}{l}\text { Exministro de } \\
\text { Grecia, jurista } \\
\text { contemporáneo }\end{array}$ & $\begin{array}{l}\text { El derecho de gentes } \\
\text { y el derecho } \\
\text { internacional antes } \\
\text { y después de la } \\
\text { conquista y la } \\
\text { fundación de América }\end{array}$ \\
\hline Roberto Almagia & Italia & $\begin{array}{l}\text { Prof. Universidad de } \\
\text { Roma }\end{array}$ & $\begin{array}{l}\text { La ciencia náutica y la } \\
\text { geografía de la época } \\
\text { colombina }\end{array}$ \\
\hline Alfonso Caso & México & $\begin{array}{l}\text { Prof. Universidad } \\
\text { Nacional }\end{array}$ & $\begin{array}{l}\text { Los sucesores de Cortés } \\
\text { en México en el } \\
\text { siglo Xvi }\end{array}$ \\
\hline
\end{tabular}


Anexo 1

PROPUESTA DE AUTORES Y VOLÚMENES (concluye)

\begin{tabular}{|c|c|c|c|}
\hline Autores propuestos & País & Cargo/profesión & Volúmenes \\
\hline Alfonso Reyes & México & $\begin{array}{l}\text { Escritor y poeta } \\
\text { eminente de México } \\
\text { y de la lengua } \\
\text { española }\end{array}$ & $\begin{array}{l}\text { El oro, la plata y } \\
\text { las esmeraldas } \\
\text { de América }\end{array}$ \\
\hline Ofsen & Noruega & $\begin{array}{l}\text { Prof. Universidad de } \\
\text { Oslo }\end{array}$ & $\begin{array}{l}\text { El descubrimiento de } \\
\text { América por noruegos } \\
\text { y normandos en la } \\
\text { Edad Moderna }\end{array}$ \\
\hline Antonio de Ulloa & Perú & $\begin{array}{l}\text { "Calificado por su } \\
\text { experiencia en estos } \\
\text { estudios" }\end{array}$ & $\begin{array}{l}\text { Los navegantes y } \\
\text { los descubridores } \\
\text { después de Colón } \\
\text { en el siglo XVI }\end{array}$ \\
\hline Carlos A. Romero & Perú & $\begin{array}{l}\text { Director de la } \\
\text { Biblioteca Nacional } \\
\text { en Lima }\end{array}$ & $\begin{array}{l}\text { La educación y la } \\
\text { imprenta en América } \\
\text { en el siglo XVI }\end{array}$ \\
\hline Riva Agüero & Perú & $\begin{array}{l}\text { Presidente del Consejo } \\
\text { y ministro de } \\
\text { Asuntos Extranjeros }\end{array}$ & $\begin{array}{l}\text { La organización de } \\
\text { poderes en América } \\
\text { en el siglo XVI }\end{array}$ \\
\hline M. da Veiga Simoès & Portugal & $\begin{array}{l}\text { Ministro de Portugal } \\
\text { en Alemania, } \\
\text { especialista en } \\
\text { náutica antes de } \\
\text { Colón }\end{array}$ & $\begin{array}{l}\text { Las rutas del atlántico } \\
\text { y los navegantes } \\
\text { portugueses del } \\
\text { siglo xv }\end{array}$ \\
\hline M. Parra Pérez & Venezuela & $\begin{array}{l}\text { Ministro de Venezuela } \\
\text { en Roma }\end{array}$ & $\begin{array}{l}\text { Conquistas y } \\
\text { organización de } \\
\text { Venezuela }\end{array}$ \\
\hline
\end{tabular}

